\title{
LAVA CAVES OF GRANDE COMORE, INDIAN OCEAN: AN INITIAL RECONNAISSANCE, SEPTEMBER 1997
}

\author{
Gregory J. Middleton*
}

\begin{abstract}
What are believed to have been the first speleological investigations in the Comoros Islands were carried out on Grande Comore island between 7 and 13 September 1997. A number of caves were located with the help of local informants and the more significant ones surveyed. Exploration of some caves was not able to be completed. The potential for further significant discoveries is believed to be high.
\end{abstract}

Keywords: vulcanospeleology, lava tubes, Comore Islands

\section{BACKGROUND}

When Bill Halliday appointed me to the Commission on Volcanic Caves in October 1996 he asked me to assume responsibility for the Indian Ocean islands (because of my efforts in documenting the lava caves of Mauritius and my interest in Madagascar). He pointed out that the Comoros were virtually unknown territory, speleologically, the only information he had being a verbal report from the French vulcanologist, Haroun Tazieff, who had been in Grande Comore some years before as a consultant during construction of the airport and noted lava caves intersected by the works.

I was able to visit the Comoros briefly, in September 1997, following the $12^{\text {th }}$ IUS Congress and, thanks to a Mauritian acquaintance then resident on the island and a tourist guide she contacted, was able to inspect a few of the island's lava caves.

The Comoros, more properly known as the Federal and Islamic Republic of the Comoros (or République Fédéral et Islamique des Comores - R.F.I. Comores) consisted of three islands (Grande Comore or Ngazidja - 1025 sq.km. ${ }^{1}$, Anjouan or Ndzuani - 424 sq.km., and Mohéli or Mwali - 211 sq.km.) located in the Indian Ocean about $600 \mathrm{~km}$ west of the northern tip of Madagascar (Fig. 1). A fourth island, Mayotte or Maore - 374 sq.km. - is geographically part of the group but, following a referendum in 1974, remains a French Collectivité Territoriale. Since its unilateral declaration of independence in 1975 RFI Comores has claimed Mayotte as part of its territory - but it now faces a much bigger problem keeping even the three islands together. Anjouan (and possibly Mohéli) declared its independence from the federation shortly before my visit, resulting in considerable political instability. Despite demonstrations, curfews and rumours of impending coups, I was able to carry out my investigations with little difficulty.

The Comoros are entirely of volcanic origin, having begun to emerge from the sea about 15 million years ago (Swaney \& Willox 1994). Mayotte is the oldest, followed by

\footnotetext{
* Member, IUS Commission on Volcanic Caves, Sydney Speleological Society, Southern Tasmanian Caverneers. P.O. Box 269, Sandy Bay, Tas. 7006 Australia.

I For comparison, Mauritius is 1825 sq. km., Flinders I. in Bass Strait is 1374 sq. km, Hawaiian island of Kauai is 1437 sq. km.
} 


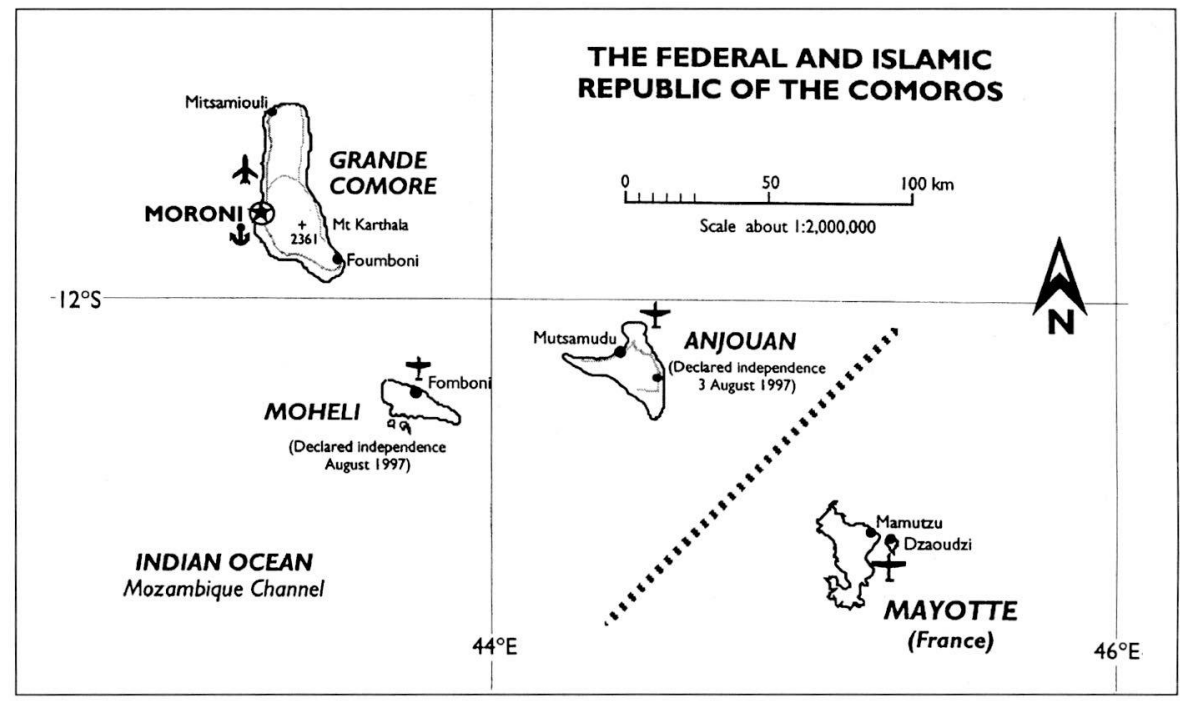

Fig. 1 - The Comoros Archipeligo.

Anjouan, Mohéli and, finally, Grande Comore, the largest island and the only one to still have an active volcano, $2361 \mathrm{~m} \mathrm{Mt} \mathrm{Karthala}{ }^{2}$.

A search of the international speleological literature confirmed Bill's view that there was no published documentation on the caves of the Comoros. However, it must be acknowledged that the Lonely Planet guidebook, Madagascar \& Comoros (Swaney $\&$ Willox 1994) does mention "the small cave, Grotte du Capitaine Dubois", but it gives only its location.

\section{LAVA CAVES INVESTIGATED}

I engaged a tourist guide, Ahmed Said, to show me the caves he knew of and to locate others reported by the local office of tourism.

The local people, numbering about 220,000 and of whom 99\% are Moslems, display an almost total lack of interest in (or outright fear of) caves. I was told they are regarded as the likely dwelling place of malevolent spirits known as djinns or ndgins (genies). Whatever the reason, very few caves appear to have been entered and they are not generally used for rubbish dumping as is the case in Mauritius. Even my guide, although he knew of a number of entrances, had entered none of them and had no idea how long any of the caves were.

1: Hilimandsodé or Grotte du Capitaine Dubois is shown on the IGN 1:50,000 map of Grande Comore and is mentioned by Swaney \& Willox (1994). It lies at a height of about $860 \mathrm{~m}$ asl, about $6.5 \mathrm{~km}$ inland, north-east of the capital. Stone steps lead up to the western side of the very obvious entrance which faces approximately south. The opening is $12 \mathrm{~m}$ wide and up to about $10 \mathrm{~m}$ high, but unfortunately only about $6 \mathrm{~m}$ deep (Fig. 2). The floor is smooth, composed of crushed lava, obviously modified by human

\footnotetext{
2 See Volcano World web site: http://volcano.und.nodak.edu/vw.html.
} 
activity over a long period. My guide claimed that a hole about $4 \mathrm{~m}$ above the floor on the eastern side of the cavern lead to a descent of some 400 metres! It was not possible to investigate this directly but the hole was subsequently found to connect with a small higher chamber.

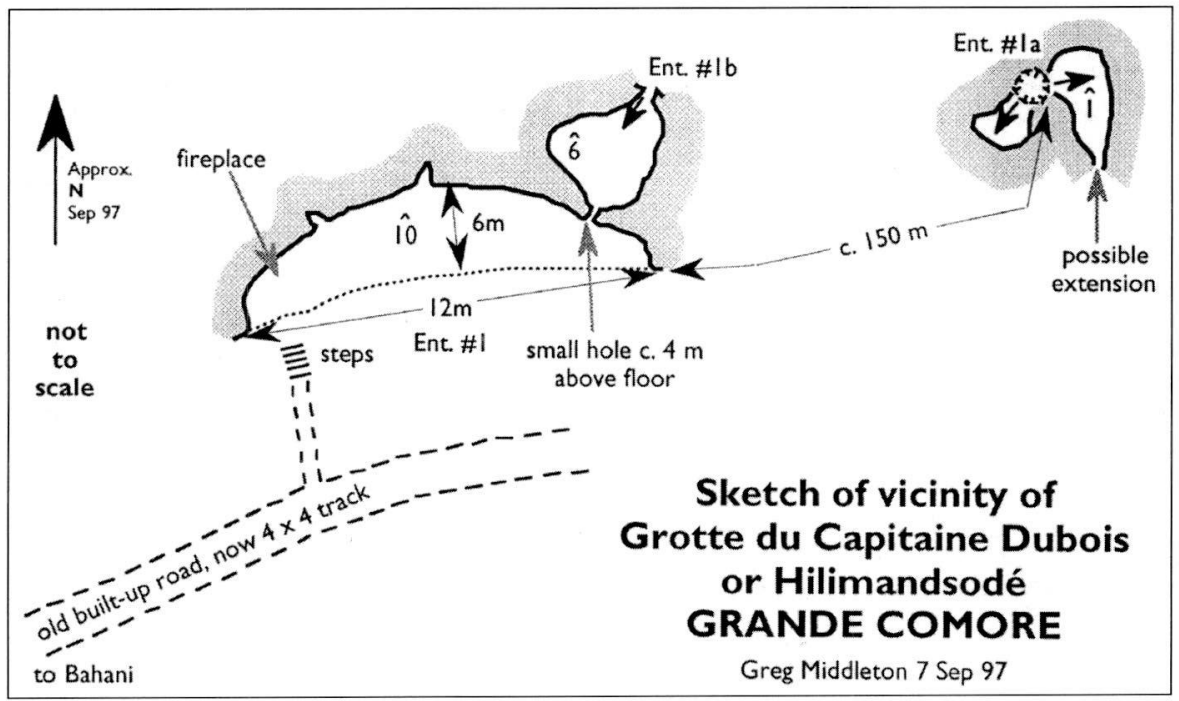

Fig. 2 - Sketch of vicinity of Grotte du Capitaine Dubois.

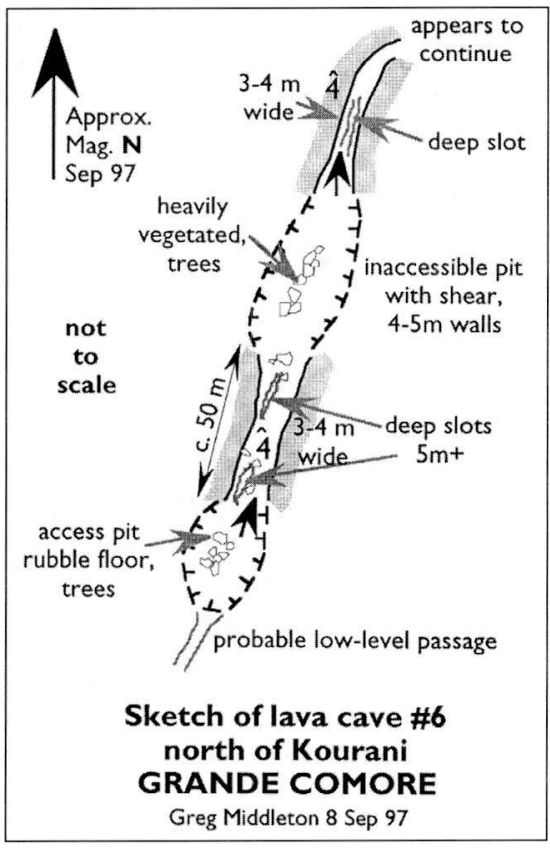

Fig. 3 - Sketch of cave 5 north of Kourani.

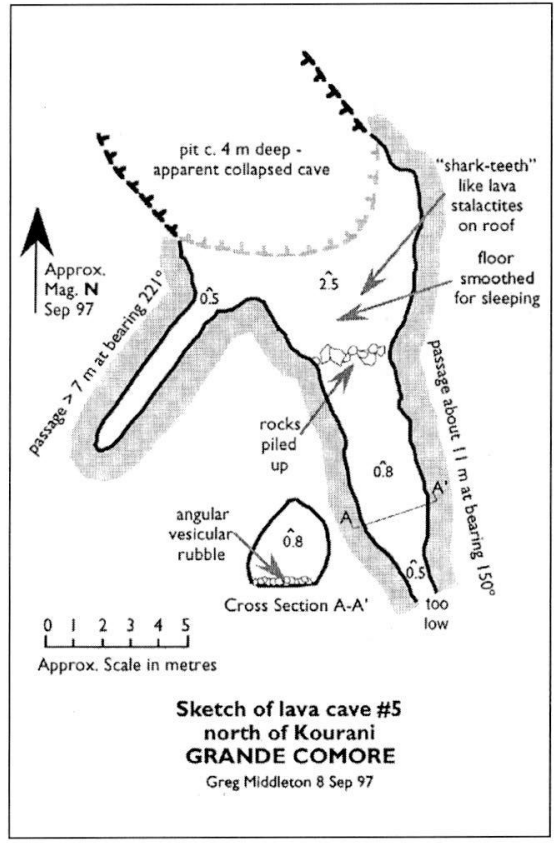

Fig. 4 - Sketch of cave 6 north of Kourani. 
1a: A small heavily vegetated hole about $150 \mathrm{~m}$ from 1 , on the side of the same hill. It is about $4 \mathrm{~m}$ in diameter and drops about $3 \mathrm{~m}$ to a rockpile. Straight ahead the hole goes down about $10 \mathrm{~m}$ but is sealed by the rockpile. A small space below the point of entry leads to a cavity with a solid roof, with small lava stalactites on the ceiling, and rubble floor. To the right it is possible to crawl for about $6 \mathrm{~m}$ until the space becomes too tight. It is possible that the hole continues but is very restricted and unstable. There is no noticeable draught.

1b: This small hole, located on the opposite side of the hill from 1 , is about $1.5 \mathrm{~m}$ in diameter and leads down into a chamber about $6 \mathrm{~m}$ by $4 \mathrm{~m}$, and around $3 \mathrm{~m}$ high. To the right is an aven perhaps $6 \mathrm{~m}$ high but not, apparently, reaching the surface. The only other feature is a small hole to the lower left, through which daylight is visible. Investigation revealed this to be the other side of the hole $4 \mathrm{~m}$ above the floor of 1 .

2: This is a vertical entrance near the junction of Route Nationale 5 and Route Régionale 118, near the village of Simboussa. Immediately north of RN5 is a pit about $3 \mathrm{~m}$ in diameter and perhaps $6 \mathrm{~m}$ deep. Naturally, such a convenient hole has collected some rubbish. Without climbing gear descent appears impossible, unless one is prepared to rely on some convenient tree roots.

3: About half an hour's walk from the village of Kourani, on the lower slopes of Mt Karthala, there is a small hole on the right side of the path, about a metre in diameter. It appears to go down at least $4 \mathrm{~m}$, but gets progressively tighter. Ahmed had not entered it (as with all the caves he knew of). I did not attempt to descend it.

4: A further half hour's walk brings one to a smaller hole on the left side of the path. It is quite narrow and part filled with sticks and banana leaves. One can see down 3 to $4 \mathrm{~m}$ but entry would not be possible for a normal adult.

5: In another 10 minutes one comes to another hole to the right of the path. There is a descent of about $3 \mathrm{~m}$ into what is obviously a collapsed lava tube, running approx. north-south and about $5 \mathrm{~m}$ wide. At the southern end is a section of intact tube about $2.5 \mathrm{~m}$ in diameter, though it narrows rapidly. One can scramble in a total of $11 \mathrm{~m}$ before the roof comes down to about $0.5 \mathrm{~m}$ high (Fig. 3). The floor is composed of very jagged pieces of vesicular rubble and short lava stalactites hang from the ceiling. A couple of metres inside the entrance rocks have been piled up, forming a wall and leaving a level area where people have obviously made camp. A smaller tube enters on the right side but it is only about $0.6 \mathrm{~m}$ in diameter and perhaps $7 \mathrm{~m}$ long.

6: Well south of the previous holes, in forest on the edge of a clearing, is a quite large and complex hole. It is 5-6 m wide and trees have grown in and fallen into it (Fig. 4). A loose rubble slide leads down about $5 \mathrm{~m}$ to where one can see into a narrow slot which appears to extend at least another 4-5 m below. The slot is 3-4 m across at the top, but becomes more narrow below. It is possible to get down another two metres or so to a level where boulders are lodged in the slot, making access possible towards the north. In a southerly direction the slot appears to continue at a lower level but with no base in sight. The section of cave to the north is about $50 \mathrm{~m}$ long before the roof opens again into a large collapsed section, 5-6 m wide with many growing trees and everything heavily covered in moss. After perhaps $100 \mathrm{~m}$ the roof closes over again and the passage continued on about $3 \mathrm{~m}$ wide and $4 \mathrm{~m}$ high. The floor was unstable here, too, and the slot continues down to undetermined depths. Sections of the wall peel off if held onto and the whole place is not particularly stable. One can descend about $4 \mathrm{~m}$ further but the slot is blocked at various levels with highly angular rocks which are not very strong.

7 \& 8: Further south, on both sides of road RR125, not far above Nioumamilima, Ahmed pointed out holes which have vertical sides and descend 5 to $6 \mathrm{~m}$, not unlike 2 . 


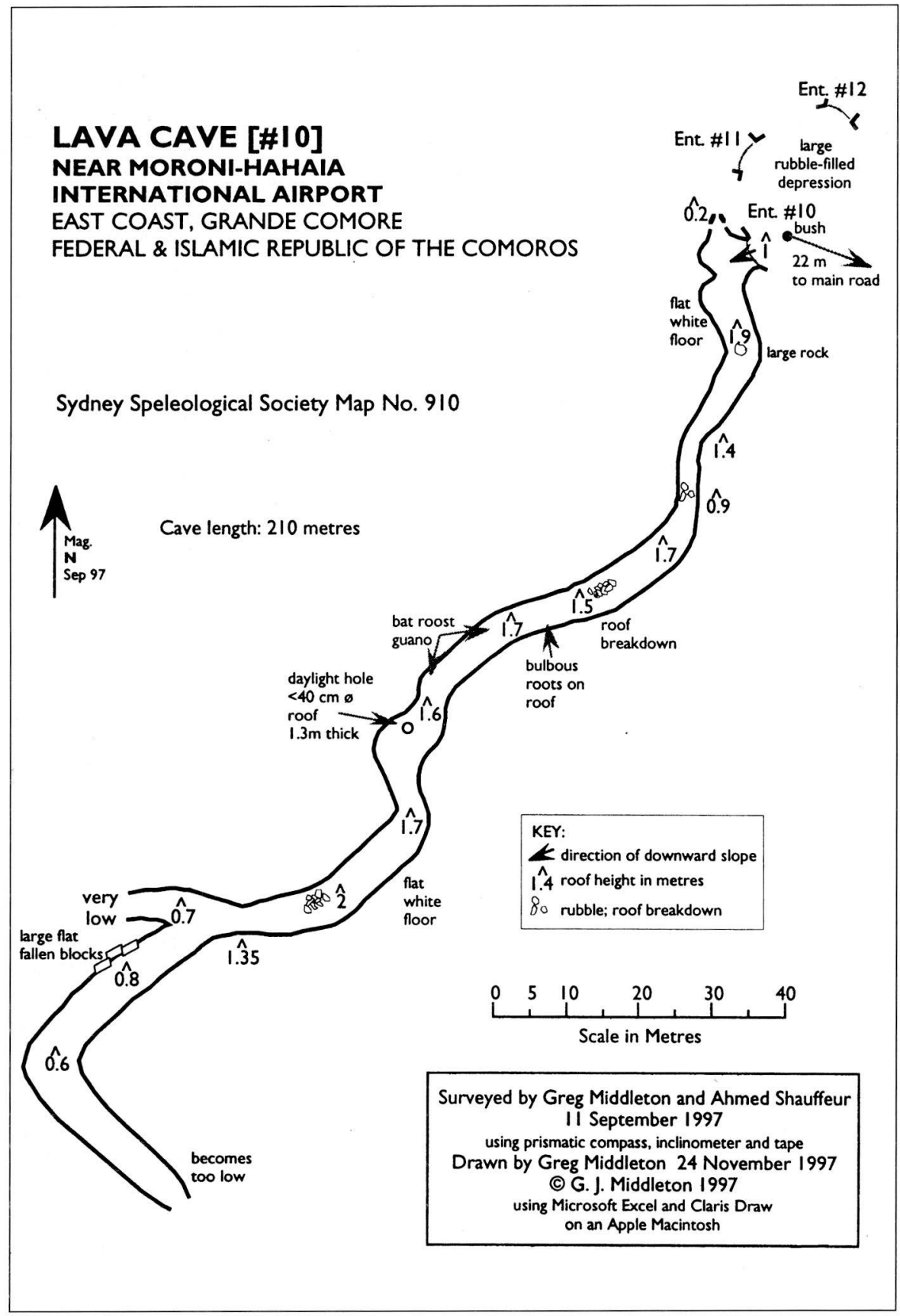

Fig. 5 - Lava Cave 10 near Moroni-Hahaia Airport, Grande Comore 
Neither appears free-climbable but they are evidently connected, meaning the road crosses a narrow bridge of lava between them. Ahmed suggested that these two holes, together with 6 , a few hundred metres north, and $2,3.5 \mathrm{~km}$ to the south, form part of a system. Certainly these holes are aligned and succeed each other downslope from the main volcano but it seems unlikely that an accessible tube connects them. Only investigation by a properly equipped team could resolve this.

9: lies about $100 \mathrm{~m}$ directly below the sawmill at the abandoned village of Nioumbadjou. It is a small cavern with a $7 \mathrm{~m}$ wide entrance, $2 \mathrm{~m}$ high and $4 \mathrm{~m}$ maximum depth. The floor is dirt, covered with a maze of roots.

10: This entrance, near two others, lies within $22 \mathrm{~m}$ of the main east coast road (RN1) adjacent to the runway of the main international airport. This is the lowest of the three holes and looks least promising, yet it leads to over $200 \mathrm{~m}$ of accessible passage, most of it less than $1.8 \mathrm{~m}$ high. The floor is generally solid, smooth and clean, with little breakdown; eventually it just becomes too low. A survey was carried out, with the help of Ahmed (Fig. 5), though he complained most of the time about the bad odours, lack of oxygen, heat, hitting his head, bending his back and being attacked by "les ouiseaux" (actually they were small insectivorous bats - which of course didn't 'attack' but he had apparently only ever seen the large Pteropus fruit bats, didn't know about the smaller ones and took a lot of convincing they weren't birds). There were perhaps 50 bats in the cave and only a few small patches of guano. Where tree roots come through the ceiling (which at the entrance is only $0.9 \mathrm{~m}$ thick, increasing to $1.3 \mathrm{~m}$ at a daylight hole) they form round balls on the ceiling and rarely reach the floor.

11: This cave was also surveyed (Fig. 6). After only about $50 \mathrm{~m}$, a $4 \mathrm{~m}$ undercut drop impedes further access without a rope. The lavafall has produced a typical plunge pool with a widened passage at its base, narrowing again beyond. A rope was obtained to enable safe descent of this drop. Although overhung, there are footholds which facilitate the climb. At the "plunge pool" the passage is about $9 \mathrm{~m}$ high. It then narrows to about $6 \mathrm{~m}$ and the roof descends to about $6 \mathrm{~m}$ high. The floor is in places clean and level but elsewhere is strewn with slabs of rock fallen from the roof. A survey was carried out for about another $300 \mathrm{~m}$ before a failing lamp forced its termination. At this point the passage, which is $10 \mathrm{~m}$ wide and $2.5 \mathrm{~m}$ high, splits in two, both about $8 \mathrm{~m}$ wide. A large crab was noted here, moving around in a narrow slot. The passage heads towards the sea (and the airport runway) but at this point is at least $600 \mathrm{~m}$ from the shore. It could be that small spaces in the underlying rock allowed the crab to penetrate to this point, though the benefits are not immediately obvious. It is likely that if the passage reaches the vicinity of the airport runway it would have been detected when the airport was built and would have been collapsed and filled.

12: This hole, near 10 and 11, is blocked by a rockfall after only about $20 \mathrm{~m}$ (Fig. 7), clearly the result of earthworks related to the main road (RN1) which it would have passed underneath. A search upslope might reveal another access point.

13: The tourism office reported a cave near the coastal village of Fassi. A youth from the village, Yousoof Alismael, showed us the cave and said it is known as "Nyamaoui" and that the Comorian word for cave is "panga". The entrance is at least $500 \mathrm{~m}$ inland, in extremely dry, poor, country. The entrance pit, hidden in vegetation, is about $20 \mathrm{~m}$ in diameter and $10 \mathrm{~m}$ deep. The vertical sides of the pit make unaided access impossible but one of two large trees growing in it has a trunk growing quite close to the lip which makes descent (and ascent) possible. At the bottom there are two large passages; one leads west, towards the coast, and the other, east, or inland. That to the east was clearly larger ( $7.5 \mathrm{~m}$ wide by $5 \mathrm{~m}$ high) and so was checked first. At the top of the scree at the tunnel entrance, a dry stone wall about $1.5 \mathrm{~m}$ high has been built almost 


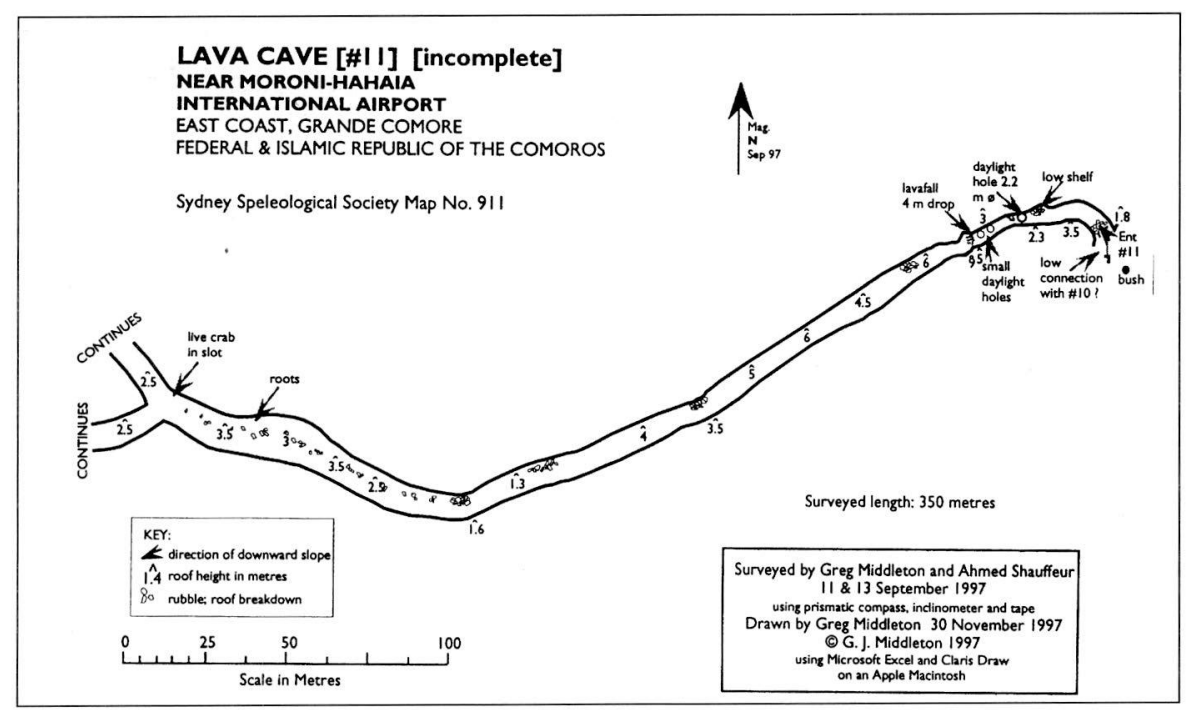

Fig. 6 - Lava Cave 11 near Moroni-Hahaia Airport - exploration incomplete.

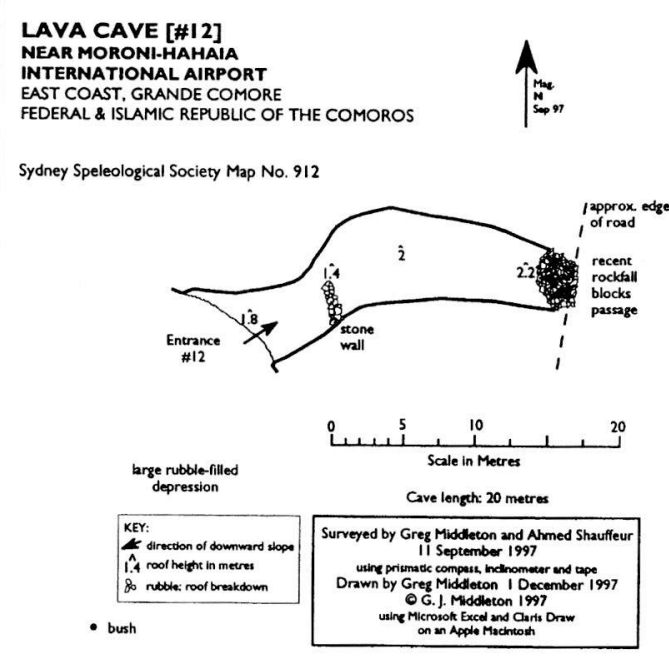

Fig. 7 - Lava Cave 12 near Moroni-Hahaia Airport.

right across the entrance, for a purpose unknown. At the northern end of the wall was a very old large ceramic vessel which may have been used to carry water. The eastern passage reduces in height as one goes further in and the floor is covered with irregular roof breakdown. A smaller passage branches off to the south, leading to a bat chamber after about $20 \mathrm{~m}$. A few metres further on the main passage narrows and the ceiling lowers to about $2.5 \mathrm{~m}$ but it then rapidly rises and the passage widens out again. About 


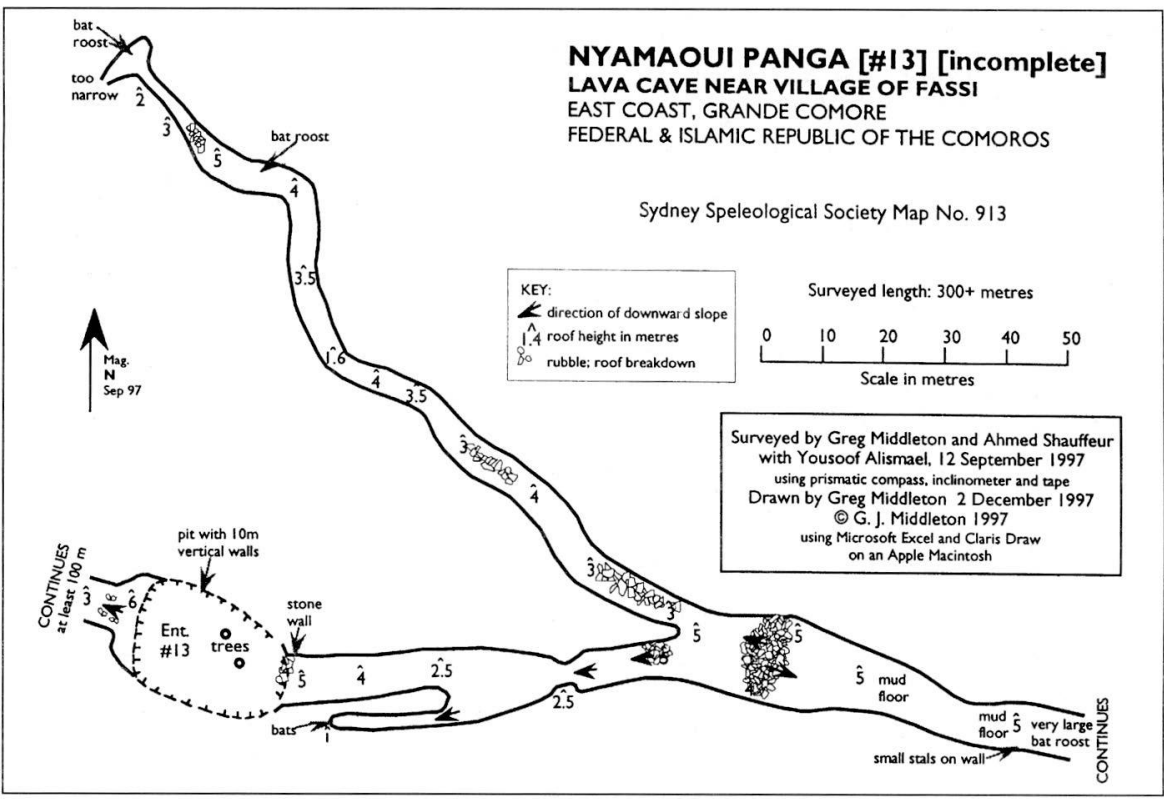

Fig. 8 - Nymaoui Panga (13), a lava cave near Village of Fassi, Grande Comore - exploration incomplete.

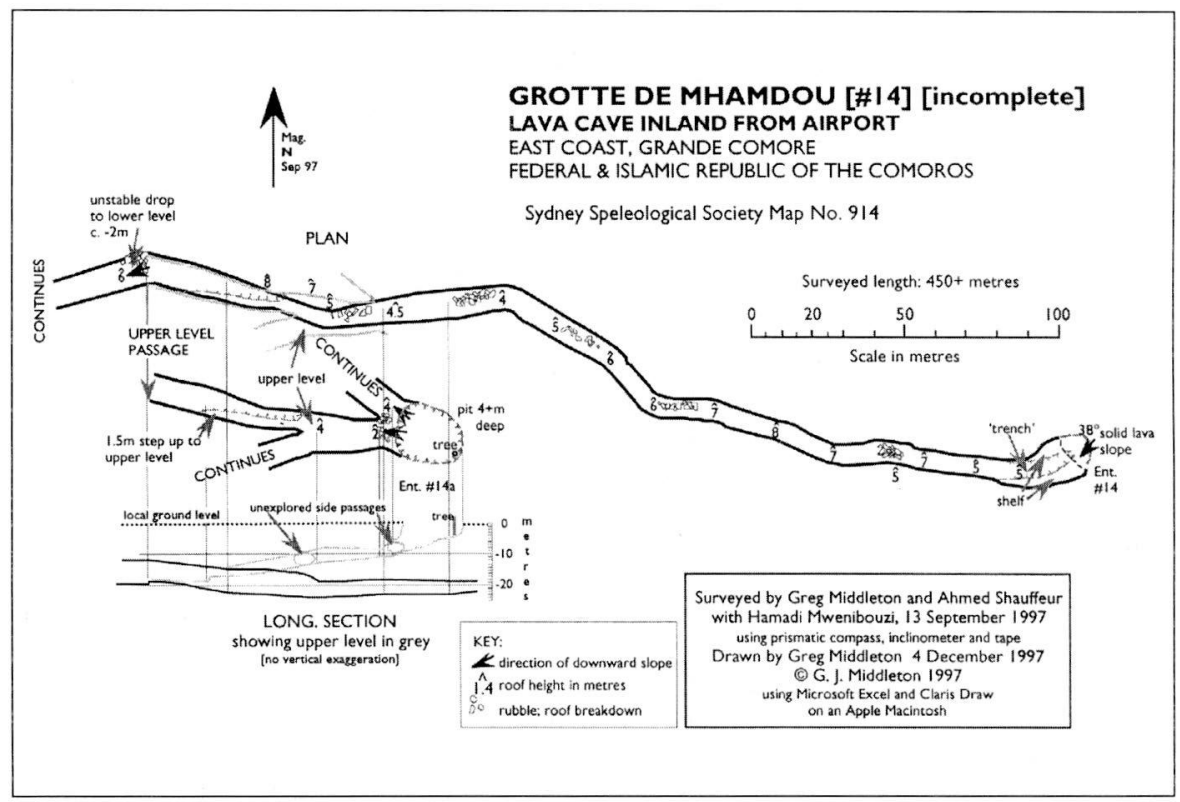

Fig. 9 - Grotte de Mhamdou (14), a lava cave inland from the Airport, Grande Comore - exploration incomplete. 
$15 \mathrm{~m}$ further in a large passage comes in from the north-west. This appears to end, after about $150 \mathrm{~m}$, in a bat roost but a small passage may continue. Continuing east in the main passage ( $8 \mathrm{~m}$ wide $\times 5 \mathrm{~m}$ high), one climbs over a rockpile to a mud floor. At this point one encounters a huge bat roost; the floor is thickly covered in guano and large numbers of very light-coloured cave crickets are evident.. We terminated our exploration at this point as we did not wish to further disturb the bats. The passage shows no sign of decreasing in size. The passages were surveyed as we returned to the entrance (Fig. 8). From the entry pit a rock scree leads down into the western passage which is then more or less level; it was checked for about $100 \mathrm{~m}$ but not surveyed. It is about 4 $\mathrm{m}$ wide and $5 \mathrm{~m}$ high and shows no sign of tapering. This cave is clearly a highly significant one, with an extremely large bat population.

14: also in the airport area, was shown to us by a local farmer, Hamadi Mwenibouzi, who told us it was known as Grotte de Mhamdou. The entry hole is perhaps 15 $\mathrm{m}$ in diameter. This hole is unusual, and distinctive, in that entry can easily be made down a solid lava flow, rather than the usual pile of roof breakdown or vertical face. The cave is 5 to $6 \mathrm{~m}$ wide and from 4 to $8 \mathrm{~m}$ high, with breakdown material covering the floor after the entrance chamber, which has a distinct cleft cut (?) in the centre of the floor. About $350 \mathrm{~m}$ of the cave was surveyed (Fig. 9), to a point where daylight is visible from a higher level. The passage continues beyond this point but requires a descent of a steep, unstable section. It is possible to climb up to a shelf at the higher level which is about $4 \mathrm{~m}$ high. Proceeding towards the pit which is the source of the daylight, one passes passages on both right and left, each about $4 \mathrm{~m}$ high and 5 to $7 \mathrm{~m}$ wide. Both appear to continue but were not investigated. The survey shows we had explored over $450 \mathrm{~m}$ of passage - and left three passages unexplored.

15: lies on the eastern side of the main road; before construction of the road it may have been connected to 12 . The entrance is about $6 \mathrm{~m}$ wide and $2 \mathrm{~m}$ high. In the entrance chamber were two old truck tyres. A passage about $6 \mathrm{~m}$ wide $\mathrm{x} 4 \mathrm{~m}$ high runs inland for about $80 \mathrm{~m}$. The floor is fairly clean until the substantial roof fall which appears to block the passage - though it is possible that there may be a way around it to the right.

At the village of Bangoua Kouni I sought information on a cave reported by the tourism office. We were directed to a spot on the north side of the main road (RN3), a couple of hundred metres SW of the village. Here a local youth pointed to a jumble of broken rocks and said that the cave entrance had been filled a few years earlier when the road was widened. It was evident that we had no hope of re-opening this cave without official sanction and machinery or labourers.

\section{OTHER REPORTED CAVES}

1. In the south-east, a cave is reported in the vicinity of Gama Mbwebe (Tourist Office).

2. Cave containing water, "on the other side of the island", in which a man is said to have died (reported by guide).

3. The 1:50,000 topo map shows a 'Grotte de Milembeni' inland from the village of Mbatse, near the east coast.

4. The 1:50,000 topo map shows 'Gouffre' near the edge of the crater on the summit of Mt Karthala at a height of 2,260 m a.s.l. 


\section{RECENT MAJOR LAVA FLOW}

I also visited a recent lava flow, reported to have occurred in 1977 , in the vicinity of the village of Singani ${ }^{3}$. This town has been rebuilt since the flow, which, according to Swaney \& Willox (1994, p. 348), left only the school standing. The higher part of the flow (above road NR2 at about $400 \mathrm{~m}$ asl) is now almost completely covered by lichen, with many ferns. Below the road, however, the rock appears to be much darker (almost black) and there is hardly any vegetation. The rock is highly vesicular and friable aa lava. It decomposes into a sort of sand very readily and is being worked to extract that material for building. In some places cave-roof-like structures are exposed, composed of stronger grey basalt but they are invariably filled with the vesicular, friable material. This latter material does not appear strong enough to form a stable tube roof. Inspection of a fair part of this new flow revealed no evidence of holes, collapses or tubes. The rock forms beautiful natural sculptures in places, though this is readily destroyed when the land is levelled.

\section{OFFICIAL SUPPORT}

Before leaving, I attended a meeting with an advisor to the President who expressed great interest in my investigations and their possible value to the country. He also indicated an awareness of the country's environmental problems and a wish to see the remaining natural environment protected by a national park - after the current political problems are resolved. He expressed his full support for the continuation of the investigation of the island's caves.

\section{CONCLUSION}

I conclude that there are a large number of significant caves on Grande Comore, especially in the north where the gradients are more gentle. The potential for the finding of further caves is extremely high. There has been no interest in the caves locally and the fear of spirits which may inhabit them has probably protected the caves and their contents from damage by casual visitors. The search for water, which has been a scarce resource (there appear to be no permanent watercourses on the island), may have at times enticed people underground and this is reported (by my guide) to have led to the death of a man looking for water when his flaming torch went out.

A small, well-equipped team, would be necessary to complete the exploration of some of the caves I located and, in cooperation with knowledgable locals, would have a good chance of finding more significant lava tube caves on Grande Comore.

My sincere thanks to Rosemay Oxenham who made my stay on Grande Comore much more enjoyable, and successful, than would have been possible without her, and to Dr Bill Halliday for suggesting the enterprise.

\section{REFERENCES}

SWANEY, D. and R. WILLOX. 1994. Madagascar \& Comoros - a travel survival kit. 2nd Edn. Lonely Planet Publications: Hawthorn, Australia p. 350.

\footnotetext{
3 According to Volcano World web site, the most recent eruption was a phreatic explosion in 1991
} 